\title{
EXTERNAL FIXATION FOR INTRA-ARTICULAR FRACTURES OF THE DISTAL RADIUS
}

\author{
I. JAKIM, H. S. PIETERSE, M. B. E. SWEET
}

\author{
From Hillbrow Hospital and University of the Witwatersrand, Johannesburg
}

\begin{abstract}
In a prospective study of 132 patients with an average age of 35 years, unstable intra-articular fractures of the distal radius were treated by external fixator. Only 15 cases required limited open reduction. Followup was for a mean of $\mathbf{4 2}$ months.

There were few complications and $83 \%$ of patients had good or excellent results. There was a statistically significant correlation between the severity of the fracture and the clinical outcome, irrespective of radiological restoration. Articular and soft-tissue damage following violent compressive forces may lead to a degree of functional impairment.
\end{abstract}

Comminuted intra-articular fractures of the distal radius are increasingly common after high-energy injuries, but in the past have often been reviewed together with extraarticular fractures (Szabo and Weber 1988). Intraarticular fractures occur mainly in young individuals with good bone stock as a result of violent compression forces, and are associated with substantial articular and peri-articular tissue damage.

We report the results of a prospective study of such fractures managed by external fixation, combined, in some cases with limited open reduction.

\section{PATIENTS AND METHODS}

Between 1985 and 1987 we treated 132 patients with unstable intra-articular fractures of the distal radius using the Hoffman C-series external fixator. Their ages ranged from 15 to 62 years (mean 35.3), there were 44 women and 71 men. The dominant limb was affected in $62 \%$, four fractures were compound, and 24 patients had sustained multiple injuries. Follow-up of 115 cases was

I. Jakim, MD, Senior Lecturer and Head of Department of Orthopaedic Surgery

H. S. Pieterse, FCS, Consultant Orthopaedic Surgeon

M. B. E. Sweet, PhD (Med), Consultant Orthopaedic Surgeon and Reader in Experimental Orthopaedics

Hillbrow Hospital and the University of the Witwatersrand, Johannesburg, Republic of South Africa.

Correspondence should be sent to Mr I. Jakim at the Department of Orthopaedic Surgery, Medical School, 7 York Road, Parktown 2193. Republic of South Africa.

(C) 1991 British Editorial Society of Bone and Joint Surgery $0301-620 X / 91 / 2090 \$ 2.00$

J Bone Joint Surg [Br] 1991; 73-B:302-6. from 24 to 60 months (mean 42.3), 17 failing to attend for review.

Radiographic study. On admission, symmetrical anteroposterior and lateral radiographs of both wrists were taken for comparison. The number of bone fragments and the amount of intra-articular displacement were recorded. Comminution varied from a two-part fracture

Table I. Classification of comminuted intra-articular fractures of the distal radius

\begin{tabular}{lllc}
\hline Type & Distal segment & Articular components & $\begin{array}{c}\text { Number } \\
\text { reviewed }\end{array}$ \\
\hline 1 & Undisplaced & Undisplaced & 3 \\
2 & Displaced & Undisplaced & 38 \\
3 & Displaced & $\leq 2 \mathrm{~mm}$ displacement & 26 \\
4 & Displaced & $\begin{array}{l}>2 \mathrm{~mm} \text { displacement } \\
\text { and/or rotation }\end{array}$ & 40 \\
5 & $\begin{array}{l}\text { Gross comminution, extending into the } \\
\text { metaphysis, with severe soft tissue damage }\end{array}$ & 8 \\
\hline
\end{tabular}

such as a Barton or a radial styloid fracture, through a three-part fracture in which the medial or lateral corner is split in two, to a four-part fracture comprising the radial shaft, the radial styloid, and dorsal and palmar medial fragments. Gross comminution of the articular surface may occur with or without metaphyseal fragmentation. We based our classification of severity on the amount of displacement (Table I), finding that this facilitated operative planning. Occasionally full assess- 
ment of comminution was not possible until after distraction.

Radiographs were also taken during the operation and at one, two, four and eight weeks, at three, six and 12 months, and then at yearly intervals.

Radial angle, radial length, and volar tilt were measured on post-reduction and follow-up radiographs (Gartland and Werley 1951). At final assessment any incongruity of the radiocarpal or radio-ulnar joints, radioulnar dislocation or secondary degenerative change were recorded.

Surgical technique. The external fixator was applied under general anaesthesia; this facilitated early postoperative neurological evaluation. An open technique was used to place three pins into the radius and three into the second metacarpal at $90^{\circ}$ to the dorsal surface of the bones. The pins entered the radius on its subcutaneous surface just proximal to the level at which extensor carpi radialis longus and brevis are crossed by extensor brevis and abductor pollicis longus. The second metacarpal was exposed starting from its basal flare, and taking care to avoid the extensor tendons. The distractor was placed on the radial side.

An image intensifier and control radiographs were used to monitor distraction and manipulation. If this failed to reduce the medial complex or left any articular incongruity, then percutaneous or limited dorsal open reduction was performed, using $\mathrm{K}$-wires. Any residual dislocation or subluxation at the radio-ulnar joint was reduced and fixed, if necessary, with a $\mathrm{K}$-wire, or by the addition of a volar splint, usually in supination.

Postoperative management included vigorous mobilisation of the shoulder, elbow and fingers, and patients were instructed to clean and dress all their pin tracks daily, using peroxide and sterile gauze. After removal of the fixator at eight weeks, patients had a further intensive course of physiotherapy.

Final assessment. At the latest review the outcome was graded according to the scoring system given in Table II which allocates 60 points for function and 40 points for radiographic appearance.

\section{RESULTS}

The incidence of each of the types of injury are given in Table I. Most of the injuries were caused by high-energy compression forces. Associated fractures of the scaphoid in three patients were treated by internal fixation. Median nerve damage was encountered in 11 patients of whom six required immediate surgical decompression; the others resolved spontaneously. Ulnar nerve paresis occurred once. All but one of the nerve injuries were seen with type 4 and type 5 fractures. Limited dorsal open reduction or percutaneous pinning was needed in 15: two with type 3 fractures, 11 with type 4 and two with type 5 injuries. The latter two cases both required combined dorsal and palmar approaches for open reduction.
Disruption of the radio-ulnar joint occurred in six patients and persisted in two. Supplementary bone grafting was necessary in three cases: one was a type 2 fracture which presented late and required open reduction; the other two were compound fractures with bone loss.

Table II. Scoring system for the results of treatment of intra-articular fractures of the distal radius

\begin{tabular}{|c|c|c|c|}
\hline & & & Score \\
\hline \multirow{3}{*}{$\begin{array}{l}\text { Clinical : subjective } \\
\text { (normal } 30 \text { points) }\end{array}$} & \multirow[t]{3}{*}{ Pain/function } & $\begin{array}{l}\text { None/normal } \\
\text { Mild occasional/ } \\
\text { slight limitation }\end{array}$ & $\begin{array}{l}30 \\
24\end{array}$ \\
\hline & & $\begin{array}{l}\text { Moderate, needs } \\
\text { analgesics/ } \\
\text { some limitation }\end{array}$ & 15 \\
\hline & & $\begin{array}{l}\text { Severe/weak } \\
\text { with loss }\end{array}$ & $\mathbf{0}$ \\
\hline \multirow{3}{*}{$\begin{array}{l}\text { Clinical : objective } \\
\text { (normal } 30 \text { points) }\end{array}$} & Mobility & $\begin{array}{l}\text { Normal } \\
<30 \% \text { loss of range } \\
\text { Minimal functional* } \\
\text { Less than minimal }\end{array}$ & $\begin{array}{r}15 \\
12 \\
7 \\
0\end{array}$ \\
\hline & Gript & $\begin{array}{l}\text { Normal } \\
15 \% \text { loss } \\
16 \% \text { to } 30 \% \text { loss } \\
>30 \% \text { loss }\end{array}$ & $\begin{array}{r}12 \\
10 \\
6 \\
0\end{array}$ \\
\hline & Deformity & $\begin{array}{l}\text { None } \\
\text { Slight } \\
\text { Obvious }\end{array}$ & $\begin{array}{l}3 \\
1 \\
0\end{array}$ \\
\hline \multirow{3}{*}{$\begin{array}{l}\text { Radiological: positive } \\
\text { (normal } 40 \text { points) }\end{array}$} & $\begin{array}{l}\text { Radial angle } \\
\text { (degrees) }\end{array}$ & $\begin{array}{c}23 \text { to } 18 \\
17 \text { to } 13 \\
12 \text { tol0 } \\
<10\end{array}$ & $\begin{array}{r}15 \\
12 \\
9 \\
0\end{array}$ \\
\hline & Radial length (mm) & $\begin{array}{c}13 \text { to } 10 \\
9 \text { to } 7 \\
6 \text { to } 5 \\
<5\end{array}$ & $\begin{array}{r}15 \\
12 \\
9 \\
0\end{array}$ \\
\hline & $\begin{array}{l}\text { Volar tilt } \\
\text { (degrees) }\end{array}$ & $\begin{array}{c}11 \text { to } 7 \\
6 \text { to } 3 \\
2 \text { to } 0 \\
\text { negative }\end{array}$ & $\begin{array}{r}10 \\
8 \\
6 \\
0\end{array}$ \\
\hline \multirow{3}{*}{$\begin{array}{l}\text { Radiological: } \\
\text { negative } \\
\text { (normal } 0 \text { points) }\end{array}$} & Incongruency (mm) & $\begin{array}{c}1 \text { to } 2 \\
>2\end{array}$ & $\begin{array}{l}-5 \\
-10\end{array}$ \\
\hline & Radio-ulnar joint & $\begin{array}{l}\text { Subluxation } \\
\text { Dislocation }\end{array}$ & $\begin{array}{l}-5 \\
-10\end{array}$ \\
\hline & Arthritic change & $\begin{array}{l}\text { Minimal } \\
\text { Moderate } \\
\text { Severe }\end{array}$ & $\begin{array}{l}-5 \\
-10 \\
-20\end{array}$ \\
\hline
\end{tabular}

* dorsiflexion $45^{\circ}$, palmar flexion $30^{\circ}$, radial/ulnar deviation $15^{\circ}$ each, pronation/supination $50^{\circ}$ each

† allow $+15 \%$ for dominant side

Results for the whole series are given in Table III, and are related to fracture type in Table IV. These data were analysed by the Mantel-Haenszel test; this indicated a strong relationship between fracture type and clinical score. The worse the fracture, the poorer the overall clinical outcome $(p<0.007)$. We found no correlation between fracture type and radiological appearance at follow-up $(p=0.5)$; this suggests that cartilage contusion and associated soft-tissue damage play a significant role in the ultimate result. 


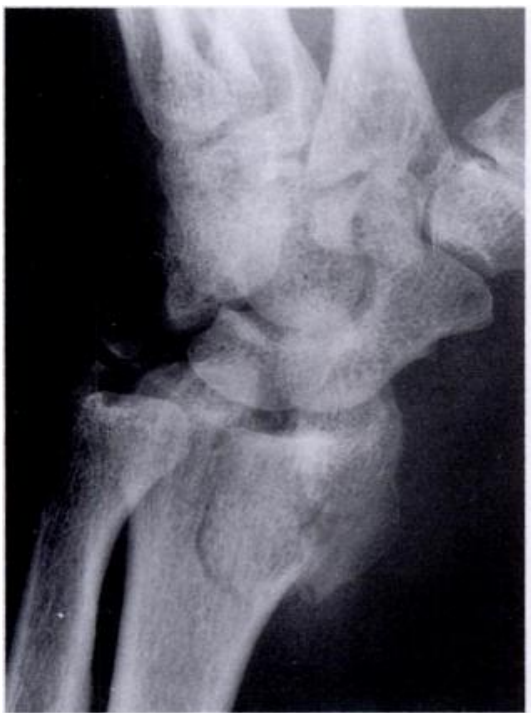

Fig. 1a

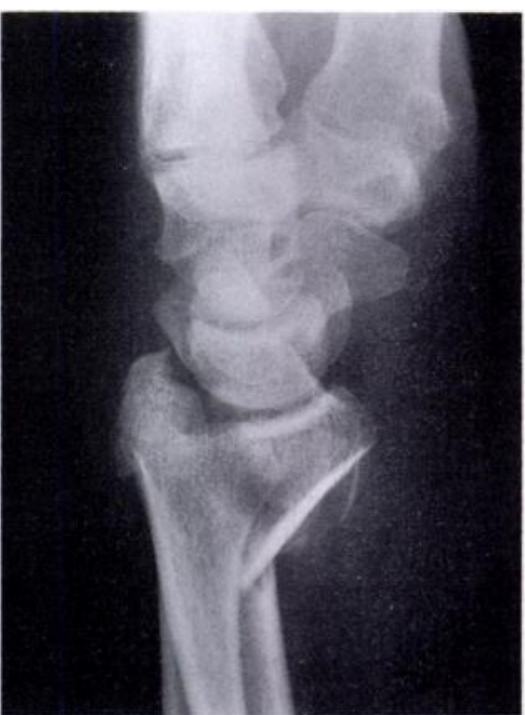

Fig. 1b

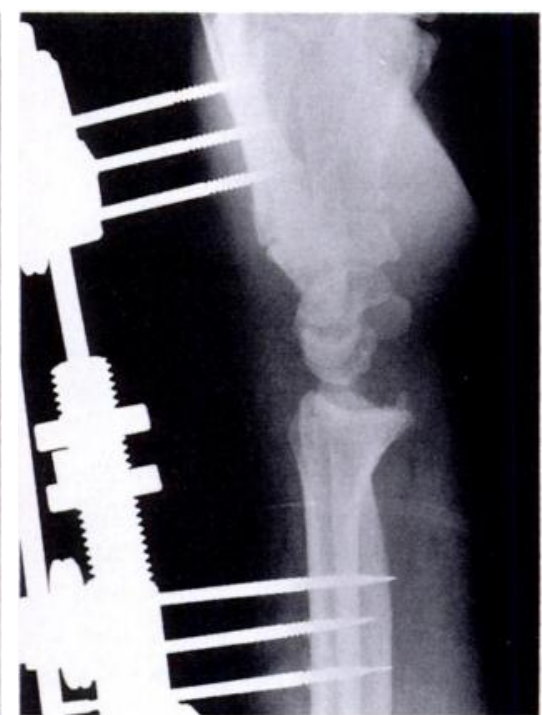

Fig. 1c

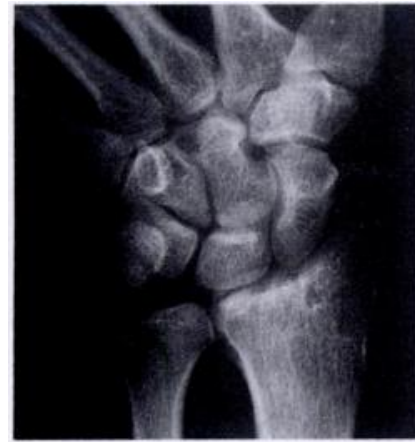

Fig. 1d

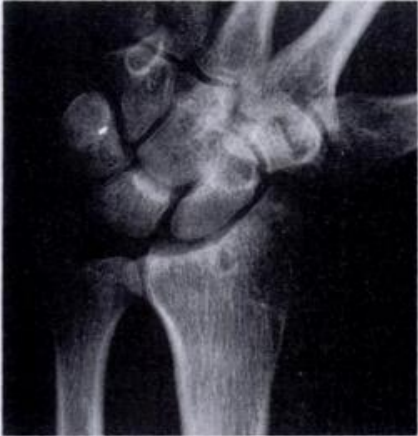

Fig. le

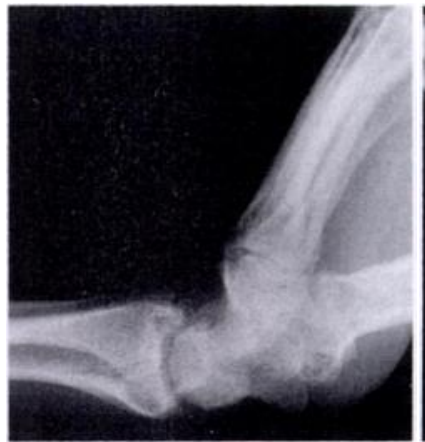

Fig. If

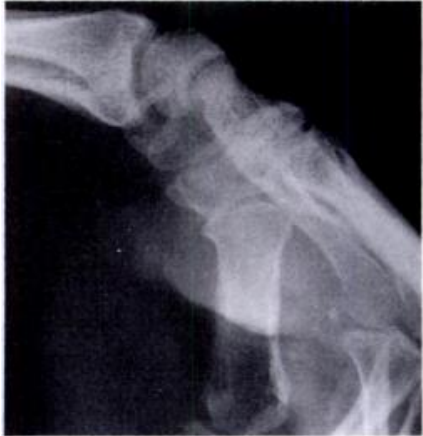

Fig. 18

A type 4 fracture in a 50-year-old man. There is severe comminution of the lateral complex, with wide separation ( $4 \mathrm{~mm})$ and rotation of articular fragments (a), and anterior displacement (b). Reduction by external fixator was successful (c). At 54 months he had an excellent range of movement and good function. $(d, e, f, g)$.

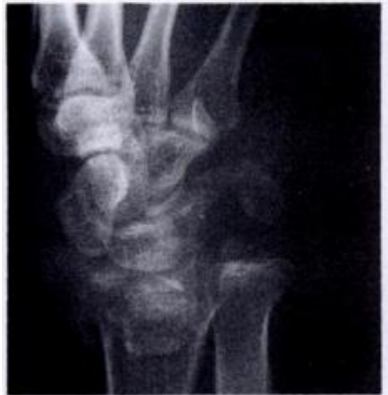

Fig. 2a

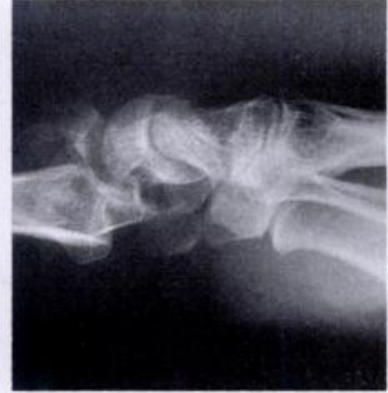

Fig. $2 b$

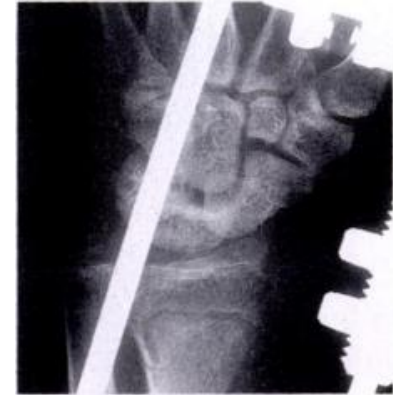

Fig. 2c

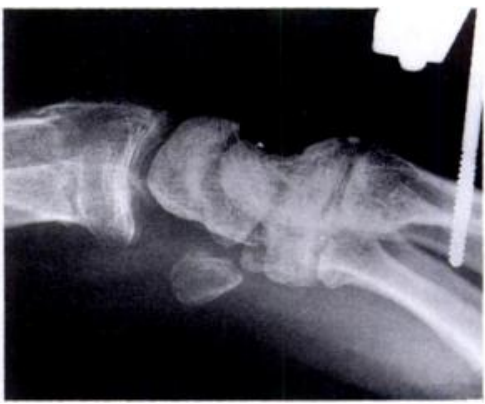

Fig. 2d

A type 4 fracture in a 36-year-old woman. There is gross comminution, shortening, disruption of the medial complex (a) and rotation of the palmar medial fragment (b). The reduction by external fixator and manipulation is good (c, d). She had an excellent clinical and radiological result.

Nevertheless, despite the severity of the injuries, $83 \%$ of our patients achieved good or excellent results (Figs 1 and 2). Radial length and angle were fully restored in most patients, but volar tilt remained unsatisfactory in $22(19 \%)$. There was some joint incongruency in five patients, all with type 4 fractures, who had been treated by external fixation alone. These patients were seen early in the series, and would now have been managed by dorsal open reduction with external fixation.

Nine patients had evidence of post-traumatic arthri- 
tis $(7.2 \%)$; five of these had joint incongruency and all had suffered seriously displaced fractures. Many patients showed early local osteopenia which invariably resolved after the removal of the fixator. Six patients regained only a minimal functional range of wrist movement; all of them had type 4 or 5 fractures. One patient with a severe crush injury (type 5) regained less than a minimal functional range of wrist movement. Five patients had restricted finger movement; this was generally related to failure to co-operate with early postoperative rehabilitation. No patient had an extensor lag of the index finger.

Grip strength was excellent in $82 \%$, fair in $10 \%$ and poor in $8 \%$. Twelve patients had residual deformity of the wrist; in four the distal ulna was prominent while the others had widening of the wrist.

Complications. Superficial pin track sepsis occurred in six patients $(5.2 \%)$, but resolved spontaneously in all. One patient had deep pin track sepsis involving bone; this cleared after the pin was removed, and treatment with oral antibiotics. There were three cases of pin loosening: reduction was lost in one.

\section{DISCUSSION}

We attributed our satisfactory results to the recognition and definition of the injury at the initial assessment, the simplicity of the technique, and to careful postoperative management.

Our earlier experience of treating these fractures by closed reduction and immobilisation in plaster, with or without transfixing pins, gave indifferent results, as also reported by Gartland and Werley (1951), Boyd and Horne (1988), and Kongsholm and Olerud (1989).

Full open reduction of severely comminuted fractures is technically difficult, if not impossible, when metaphyseal support has been lost. This method requires excessive stripping of soft tissues, and necessitates external immobilisation, leading eventually to fibrous ankylosis and a poor functional result (Stein and Katz 1975; Dobyns and Linscheid 1984). Others have advocated open reduction and internal fixation, usually with multiple Kirschner wires, followed by early mobilisation (Melone 1984, 1986; Bassett 1987; Szabo and Weber 1988). Melone (1986) failed to achieve adequate anatomical reduction reporting an average loss of radial length of $3.2 \mathrm{~mm}$, and an average loss of volar tilt of $8.5^{\circ}: 93 \%$ of his patients had some joint irregularity or degenerative change. Bradway, Amadio and Cooney (1989) using similar methods reported a $25 \%$ incidence of joint incongruity and an $18 \%$ sepsis rate.

The use of an external fixator in the treatment of unstable intra-articular fractures of the distal radius has recently received support (Cooney 1983; Nakata et al 1985; Foster and Kopta 1986; Knirk and Jupiter 1986). Opponents of this method consider that it has a high incidence of complications, most of which are related either to pin problems or inadequate reduction (Szabo and Weber 1988). We ascribe the very low incidence of pin complications in our series to the meticulous open application of self-tapping pins by hand with no softtissue tension or impingement, firm anchorage, wound closure without tension and continuous pin-track care. We believe that using three pins at $90^{\circ}$ to the dorsal surface and a quadrilateral frame gives improved rigidity and neutralises axial compressive forces.

Table III. Overall results in 115 patients

\begin{tabular}{llll}
\hline Grade & Points & Number & Per cent \\
\hline Excellent & 100 to 90 & 69 & 60 \\
Good & 89 to 80 & 26 & 23 \\
Fair & 79 to 70 & 14 & 12 \\
Poor & $<70$ & 6 & 5 \\
\hline
\end{tabular}

Distraction combined with manipulation achieved adequate reduction in most of our patients, only $27 \%$ of the type 4 and type 5 fractures requiring percutaneous or limited open reduction, usually to reduce the medial complex. Knirk and Jupiter (1986), Weber and Szabo (1986), and Bradway et al (1989), though reporting on other methods of treatment, all agree that this combined approach is the preferred management. Unlike Leung et

Table IV. Results related to fracture type (mean \pm SD), using the system shown in Table II

\begin{tabular}{lllll}
\hline & \multicolumn{2}{l}{ Clinical } & & \\
\cline { 2 - 3 } Type* & Subjective & Objective & Radiographic & Total \\
\hline 1 & $30 \pm 0$ & $29.3 \pm 1.2$ & $36.6 \pm 5.7$ & $96 \pm 6.9$ \\
2 & $28.97 \pm 2.9$ & $28.5 \pm 3$ & $35 \pm 5.1$ & $92.2 \pm 9.6$ \\
3 & $29 \pm 2.2$ & $27.3 \pm 3.8$ & $34.2 \pm 4.7$ & $90.6 \pm 9.4$ \\
4 & $27.5 \pm 3.4$ & $28.2 \pm 3.6$ & $32.7 \pm 4.7$ & $86.7 \pm 10.2$ \\
5 & $25.1 \pm 5.1$ & $24.5 \pm 5.3$ & $33.3 \pm 6.8$ & $83 \pm 13.5$ \\
\hline \multirow{2}{*}{ see Table I } & & & \\
\end{tabular}

al (1989) we consider that the addition of bone grafting is indicated only for severe bone loss; we found that small defects filled spontaneously.

The classification of these fractures which we have suggested is simple, practical and comprehensive, while providing a guide to treatment and outcome. The poorer results of the more severe injuries seemed to be due to damage to cartilage and other soft tissues.

No benefits in any form have been received or will be received from a commercial party related directly or indirectly to the subject of this article. 


\section{REFERENCES}

Bassett RL. Displaced intraarticular fractures of the distal radius. Clin Orthop 1987; 214:148-52.

Boyd LG, Horne JG. The outcome of fractures of the distal radius in young adults. Injury 1988; 19:97-100.

Bradway JK, Amadio PC, Cooney WP. Open reduction and internal fixation of displaced, comminuted intra-articular fractures of the distal end of the radius. J Bone Joint Surg [Am] 1989; 71-A: 839-47.

Cooney WP. External fixation of distal radial fractures. Clin Orthop $1983 ; 180: 44-9$.

Dobyms JH, Linscheid RL. Fractures and dislocations of the wrist. In: Rockwood CA Jr, Green DP. Fractures in adults. Vol. 1. 2nd ed. Philadelphia, etc: JB Lippincott Company, 1984:411-509.

Foster DE, Kopta JA. Update on external fixators in the treatment of wrist fractures. Clin Orthop 1986; 204:177-83.

Gartland JJ Jr, Werley CW. Evaluation of healed Colles' fractures. $J$ Bone Joint Surg [Am] 1951; 33-A :895-907.

Knirk JL, Jupiter JB. Intra-articular fractures of the distal end of the radius in young adults. J Bone Joint Surg [ Am] 1986; 68-A :647-59.
Kongsholm J, Olerud C. Plaster cast versus external fixation for unstable intraarticular Colles' fractures. Clin Orthop 1989; 241 :57-65.

Leung KS, Shen WY, Leung PC, Kinninmonth AWG, Chang JCW, Chan GPY. Ligamentotaxis and bone grafting for comminuted fractures of the distal radius. J Bone Joint Surg [Br] 1989; 71-B:838-842.

Melone CP Jr. Articular fractures of the distal radius. Orthop Clin North Am 1984; 15(2):217-36.

Melone CP Jr. Open treatment for displaced fractures of the distal radius. Clin Orthop 1986; 202:103-11.

Nakata RY, Chand Y, Matiko JD, Frykman GK, Wood VE. External fixators for wrist fractures: a biomechanical and clinical study. $J$ Hand Surg [ Am] 1985; 10-A :845-51.

Stein AH, Katz SF. Stabilization of comminuted fractures of the distal inch of the radius: percutaneous pinning. Clin Orthop 1975; $108: 174-81$

Szabo RM, Weber SC. Comminuted intraarticular fractures of the distal radius. Clin Orthop 1988; 230:39-48.

Weber SC, Szabo RM. Severely comminuted distal radial fracture as an unsolved problem. $J$ Hand Surg [Am] 1986; 11-A:157-65. 